\title{
Effects of the pneumoperitoneum in rats submitted to a unilateral nephrectomy: morphologic and functional study on the remnant kidney ${ }^{1}$
}

\author{
Efeitos do pneumoperitônio em ratos submetidos a nefrectomia unilateral: estudos \\ morfológicos e funcionais no rim remanescente
}

\author{
Luiz Sergio Santos ${ }^{2}$, Renato Tambara Filho ${ }^{3}$, Teresa Maria da Silva Figueiredo ${ }^{4}$, Guilherme Cravo ${ }^{5}$ \\ 1. Paper produced at the Surgical Internal Medicine Graduate Program of the Federal University of Paraná (UFPR) and at the Surgery \\ Techniques and Experimental Surgery Lab of the Pontifical Catholic University of Paraná (PUC/PR). \\ 2. Associate Professor of Urology at the Surgery Department of PUC/PR, Ph.D. \\ 3. Chairman Professor of Urology at the Surgery Department of UFPR, Ph.D. \\ 4. Assistant Professor of Pathology of UFPR. \\ 5. Medical student of Surgery Techniques and Experimental Surgery of PUC/PR
}

\begin{abstract}
Purpose: The aim of this experimental study is to analyze the morphologic and functional effects of the pneumoperitoneum on the remnant kidney in rats submitted to a unilateral nephrectomy. Methods: Forty-eight male adults Wistar rats , with an average weight between 240 to $350 \mathrm{~g}$, were distributed in three groups. The rats in Group 1 were subdivided into two other subgroups: Control Group 1A and 1B. Groups 2 and 3 and respective subgroups included 12 rats each. All animals were anesthetized and submitted to a puncture. Animals in Groups 2 and 3 were submitted to abdominal insufflation with $\mathrm{CO}_{2}$, during 2 and 4 hours respectively, with a constant IAP of $15 \mathrm{mmHg}$. Rats of the Control Group 1A and 1B were maintained punctured during 2 and 4 hours respectively, however, without insufflation. In the end of this period, a left nephrectomy was performed in all animals. After 4 weeks, a new pneumoperitoneum with the same duration was installed, according to the groups. After 8 weeks, the animals were submitted to euthanasia to remove the remnant kidney. Samples of blood were collected during the whole experiment to evaluated the renal function by dosing serum creatinine. The remnant kidney was analyzed microscopically to evaluate its level of glomerular hypertrophy, the number of mesangial cells, and to observe the presence of glomerular sclerosis. All groups were kept under observation and the results were submitted to statistical analysis by a longitudinal and transversal comparative study. Results: At the evaluation of residual renal function no significant clinical alteration was seen in rats submitted to pneumoperitoneum during 2 and 4 hours after a period of 8 weeks. The morphologic analysis of the remnant kidney showed no histological renal injury in the groups. Conclusion: The function and renal morphology of rats submitted to a unilateral nephrectomy were not significantly influenced by prolonged and successive pneumoperitoneum, according to this study's biochemical and histological findings.
\end{abstract}

Key words: Pneumoperitoneum. Laparoscopy. Nephrectomy. Rats.

\section{RESUMO}

Objetivo: Analisar os efeitos morfológicos e funcionais do pneumoperitônio sobre o rim remanescente em ratos submetidos a nefrectomia unilateral. Métodos: Foram utilizados 48 ratos da linhagem Wistar, adultos, machos, pesando entre 240 e $350 \mathrm{~g}$, distribuídos em três grupos. Os ratos do Grupo 1 foram subdivididos em dois subgrupos, Controle 1A e Controle 1B. Os Grupos 2 e 3 e os subgrupos contaram com 12 animais cada. Todos os animais foram anestesiados e submetidos a punção abdominal com agulha. Os Grupos 2 e 3 foram submetidos a insuflação abdominal com $\mathrm{CO}_{2}$ por 2 e 4 horas respectivamente, com uma pressão intra-abdominal (PIA) constante de $15 \mathrm{mmHg}$. Os ratos do Controle 1A e 1B foram mantidos puncionados por 2 e 4 horas respectivamente, porém sem insuflação de gás. Ao final desse período foi realizada nefrectomia esquerda em todos os animais. Quatro semanas após, novo pneumoperitônio foi instalado com o mesmo tempo de duração, conforme os grupos. Após 8 semanas os animais sofreram eutanásia para remoção do rim remanescente. Foram coletadas amostras de sangue durante todo o experimento para análise da função renal por meio da creatinina sérica. O rim remanescente foi submetido a análise microscópica para avaliação do grau de hipertrofia glomerular, contagem do número de células mesangiais e observação da presença ou não de esclerose glomerular. Os diversos grupos foram submetidos a observação temporal e a análise estatística por meio de estudo comparativo longitudinal e transversal. Resultados: A avaliação da função renal residual não evidenciou alteração de significância clinica em ratos submetidos a 2 e 4 horas de pneumoperitônio após um período de 8 semanas. A análise morfológica do rim remanescente não revelou alteração histológica sugestiva de dano renal nos grupos em estudo. Conclusão: A função e a morfologia renal de ratos submetidos a nefrectomia unilateral, não são significativamente influenciadas por prolongados e sucessivos pneumoperitônios, conforme demonstram os acha-dos bioquímicos e histológicos neste estudo.

Descritores: Pneumoperitônio. Laparoscopia. Nefrectomia. Ratos. 


\section{Introduction}

The association between oliguria an intra-abdominal hypertension was first described in 1913 by Wendt who, while studying dogs submitted to abdominal pressure higher than $30 \mathrm{mmHg}$, noticed that the animals progressed to anuria ${ }^{1}$. In 1947, Bradley and Bradley, analyzing the effects of increased intra-abdominal pressure (IAP) on human renal function confirmed the strict relationship showing that renal dysfunction may be reversed by reducing IAP to normal values ${ }^{2}$. Several experimental and clinical studies have addressed the different physiological effects of insufflating gas - usually $\mathrm{CO}_{2}$ - into the abdomen and the consequent increase of IAP which may lead to acidalkali imbalance and altered cardiovascular, pulmonary and renal physiology. In the kidney, a prolonged increase in the IAP is associated to reduced urinary output that may lead to anuria, both in humans and animals ${ }^{3}$. A reduced cardiac output and compression of the renal vein and parenchyma, in addition to systemic hormonal effects caused by the pneumoperitoneum, may lead to a reduced renal plasmatic flow, which results in a lower glomerular filtration rate and consequently lower urinary output. Such changes are, by and large, transient and disappear soon after the pneumoperitoneum is suspended. No evidence of histological or renal function changes has been seen either on the short or long term in several experimental studies ${ }^{4,5}$. Recently, live-donor laparoscopic nephrectomy has been used as the minimal invasive alternative to the traditional lumbar incision technique since it leaves the donor less prone to morbidity, reduces healing time and hospital stay, and produces less post-op pain ${ }^{6}$. Although, in theory, the technique entails increased IAP with consequent ischemic changes on the kidney to be transplanted, which may lead to impaired renal function in the receptor, recent studies have shown no histological or functional damage to those kidneys caused by such procedure whose results are comparable to the conventional open procedure ${ }^{7}$. However, the actual effects of the pneumoperitoneum on the donor's remnant kidney have not been quite established as yet.

As the use of laparoscopy has increasead in the different medical fields, the likelihood of a single patient undergoing more than one procedure should be considered. Kidney donors are currently part of this population who, having undergone a first pneumoperitoneum for kidney removal, may - for different reasons - need a new laparoscopy. The concern in such situations lies on the remnant kidney which would be, once again, exposed to the effects of increased abdominal pressure and, therefore, subject to possible damage. In order to evaluated the complications and physiological disorders imposed by a pneumoperitoneum on the remnant kidney, we have tried to assess such changes by studying animals with reduced renal mass and submitted to successive pneumoperitoneum.

This study aims at assessing, by experimental means, the morphological and functional effects of a pneumoperitoneum on the remnant kidney of rats submitted to unilateral nephrectomy, through the analysis of biochemical and histopathological changes.

\section{Methods}

The study was approved by the Commission on Animal Study Ethics of the Pontifical Catholic University of Paraná - PUC/PR (CEPA), and carried out in compliance with the provisions on animal breeding and use in studies and research set forth by Colégio Brasileiro de Experimentação Animal - COBEA (the Brazilian Association for Animal Studies). Forty-eight male Wistar rats (Rattus norvegicus albinus, Rodentia mammalia) were used, provided by PUC/PR's breeding lab, aged about 120 days and weighing around 276.1 $\pm 27.9 \mathrm{~g}$, kept confined in collective boxes with up to five rats each. The rats were kept in the lab throughout the observation period under standard conditions - temperature between 20 and $24^{\circ} \mathrm{C}$, relative humidity between 50 and $60 \%$, controlled lighting (12-hour day/night cycle: $8 \mathrm{am} / 8 \mathrm{pm}$ ), received standard feed for the species and were allowed water ad libitum. Within the 12 hours preceding the surgical procedure nothing was offered them except for potable water.

\section{Experiment design}

The study consisted basically in performing a pneumoperitoneum with $\mathrm{CO}_{2}$ at $15 \mathrm{mmHg}$ in the rats for 2 and 4 hours, followed by left-side nephrectomy that we called MPP1. A new pneumoperitoneum was performed 4 weeks later (MPP2). After 8 weeks, upon sacrificing the animals (euthanasia time, ME) the remnant kidney was removed from all animals. Rats in the control group underwent the same procedures except for gas insufflation into the abdominal cavity. The different groups were observed along time and statistical analysis was performed through longitudinal and transversal comparative study. The rats were randomly distributed, through a draw, in three groups named 1, 2 and 3. Group 1 or Control included 24 rats that were subdivided into Control $1 \mathrm{~A}$ and $1 \mathrm{~B}$ which included 12 rats each. Twelve rats constituted Group 2 and twelve others, Group 3. Rats in Group 1 were kept anesthetized and punctured for 2 hours (Control 1A) and 4 hours (Control 1B), but no pneumoperitoneum was performed, that is, the IAP was $0 \mathrm{mmHg}$. Rats in groups 2 and 3 were submitted to a pneumoperitoneum under $15 \mathrm{mmHg}$ IAP for 2 hours and 4 hours respectively. Anesthesia was induced by intramuscular injection of ketamine chlorhydrate $50 \mathrm{mg} / \mathrm{kg}$ and Xylazine $5 \mathrm{mg} / \mathrm{kg}$, and maintained by sulphuric ether inhalation with a bell-jar/mask under spontaneous ventilation. Under anesthesia, trichotomy and antisepsis of the ventral abdominal area were performed and the rats were placed in the horizontal dorsal decubitus position, the four limbs fastened to the surgical table; and the abdominal cavity was punctured with a Jelco 18G catheter introduced at the midline on the lower portion of the abdomen. The pneumoperitoneum was performed with a $\mathrm{CO}_{2}$ electronic insufflator (Instramed ${ }^{\circledR}$ IS20 , Brazil) at a maximum flow of to $2.5 \mathrm{ml} / \mathrm{min}$, connected to a gas delivery device which, in turn, was connected simultaneously to four rats until a $15 \mathrm{mmHg}$ IAP was achieved. By the end of the established period, the pneumoperitoneum was deflated by opening the catheter to the exterior. Upon completion of the first stage, the rats 
were moved to a right lateral decubitus position to undergo a left-side nephrectomy through lumbar incision. Four weeks later, at the time of the second procedure (MPP2) the same steps performed the first time regarding anesthesia, puncture of the abdominal cavity and time of exposure to the pneumoperitoneum were repeated. After an eight-week observation period, all rats were submitted to a midline laparotomy to remove the remnant kidney and were sacrificed by sulphuric ether intoxication in a closed container. For renal function assessment in the lab, blood samples were collected throughout the study for serum creatinine dosage. Comparative morphologic analysis of the removed kidney was performed at the first procedure, and the remnant kidney was analyzed as well, to see if there had been any microscopic changes at glomerular and tubular levels, as a result of the ischemia caused by the pneumoperitoneum. The 3 ìm-thick histological sections were stained with hematoxylin-eosin and the Periodic Acid Shiff (PAS) technique. The histological parameters assessed were: diameter and glomerular area, number of mesangial cells, and the existence or not of glomerular sclerosis. The histomorphological variables were achieved by measuring five glomerules per analyzed kidney in which the vascular and urinary poles were present indicating a section in the equatorial portion thereof. The morphometric assessment was performed with the Optimasâ 6.2 software for Windowsâ, coupled to an Olympus Bx50 microscope and Sonyâ video camera (Sony Inc., Japan); the application used was Line Morphometrics, previously calibrated in a micrometer. Glomerular sclerosis was defined as partial or complete alteration of the glomerules caused by deposits of subendotelial and mesangial hyaline material, increased mesangial matrix and collapse of glomerular capillaries, the tufts adhering to Bowman's capsule ${ }^{8}$. The analysis and anatomopathological interpretation were performed by a single observer who was unaware of the groups and subgroups under study. Statistical analysis of the results was performed with the "Student t" parametric test (independent and paired samples), aided by the Primer of Biostatistics software. The significance level adopted was lower than $5 \%(\mathrm{p}<0,05)$.

\section{Results}

No death or complication were recorded during the observation period. Regarding serum creatinine, the comparison beteween groups (intergroup analisys) revealed a significant difference in Group 3 (4 hours), with higher values at the first procedure (MPP1) $(\mathrm{p}=0.002)$, procedure MPP2 at 4 weeks $(\mathrm{p}=0.012)$ and at 8 weeks $(\mathrm{ST})(\mathrm{p}=0,010)$, when compared to Control group 1B-4 hours (Figure 1).

After analyzing serum creatinine at the different points during observation (intra-group analysis), significant difference was seen only in Group 2 (2 hours) when comparing MPP1 and MPP2 ( $\mathrm{p}=0.045)$, and in Control 1B when comparing MPP1 to ME ( $\mathrm{p}=0.035)$, with higher serum creatinine values being observed at the time of euthanasia (ME). Concerning the other groups no statistically significant differences were seen during the observation period (Table 1). Morphometric analisys between groups showed significant difference only in Group 2 at MPP1 when

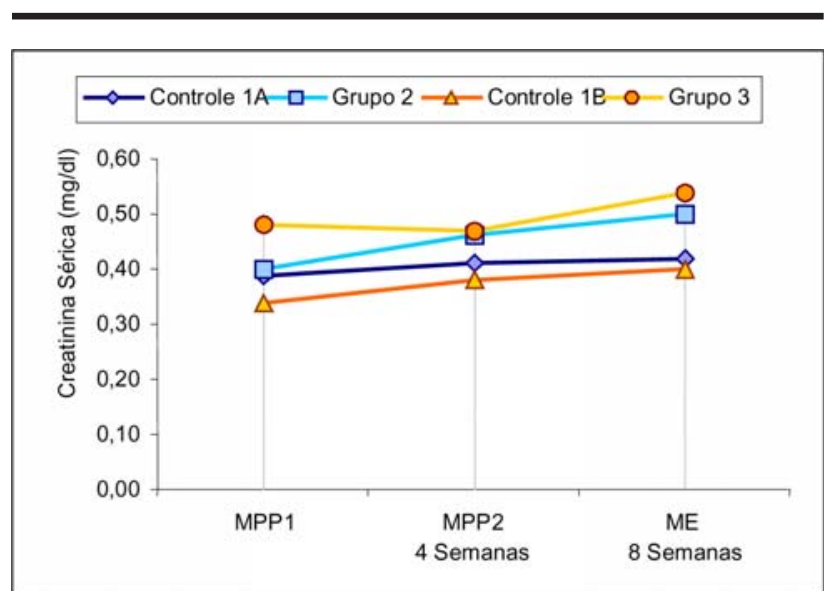

Teste $t$ student : $\quad$ Grupo3 >Controle1B. p<0,05 (MPP1;MPP2;ME) Grupo2:MPP2>MPP1 $(p=0,045)$; Grupo Contole 1B:ME $>$ MPP1 $(p=0,035)$.' FONTE: Tabela 1

FIGURE 1 - Serum creatinine evolution among the 3 groups

TABLE 1 - Statistics describing serum creatinine among the study groups (mg/dl)

\begin{tabular}{lccc}
\hline GROUPS & N & MEAN \pm SD & Min-Max \\
\hline MPP1 & 48 & $0,40 \pm 0,11$ & $(0,24-0,72)$ \\
Control 1A (2h) & 12 & $0,39 \pm 0,08$ & $(0,29-0,51)$ \\
Control 1B (4h) & 12 & $0,34 \pm 0,06$ & $(0,24-0,41)$ \\
Group 2 (2h) & 12 & $0,40 \pm 0,12$ & $(0,24-0,70)$ \\
Group 3 (4h) & 12 & $0,48 \pm 0,12$ & $(0,35-0,72)$ \\
MPP2 - 4 weeks & 48 & $0,43 \pm 0,09$ & $(0,26-0,61)$ \\
Control 1A (2h) & 12 & $0,41 \pm 0,08$ & $(0,28-0,54)$ \\
Control 1B (4h) & 12 & $0,38 \pm 0,08$ & $(0,30-0,54)$ \\
Group 2 (2h) & 12 & $0,46 \pm 0,10$ & $(0,26-0,61)$ \\
Group 3 (4h) & 12 & $0,47 \pm 0,08$ & $(0,39-0,60)$ \\
ME - 8 Weeks & 48 & $0,46 \pm 0,13$ & $(0,20-0,79)$ \\
Control 1A (2h) & 12 & $0,42 \pm 0,10$ & $(0,25-0,56)$ \\
Control 1B (4h) & 12 & $0,40 \pm 0,10$ & $(0,20-0,50)$ \\
Group 2 (2h) & 12 & $0,50 \pm 0,15$ & $(0,20-0,76)$ \\
Group 3 (4h) & 12 & $0,54 \pm 0,14$ & $(0,37-0,79)$ \\
\hline
\end{tabular}

compared to Control $1 \mathrm{~A}$ regarding mean glomerular diameter $(\mathrm{p}=0.023)$ and mean glomerular area $(\mathrm{p}=0.035)$ parameters. Among the cases reported, Group 2 showed higher values (Table 2). Also regarding the number of mesangial cells, a statistically significant difference was seen only in Group 2 when compared to Control $1 \mathrm{~A}$ in the remnant kidney analysis at $\mathrm{ME}(\mathrm{p}=0.033)$ - Table 2 . In the comparative morphometric study between the kidney removed in the first procedure (MPP1) and the remnant kidney (ME) (intragroup analysis) no significant difference was seen regarding any of the above mentioned histological parameters. No histological alterations were evidenced that might suggest glomerular lesion characterized by segmental or focal sclerosis at the different times among the study groups were evidenced. 
TABLE 2 - Morphometric study among the groups - MPP1/ME

\begin{tabular}{|c|c|c|c|c|}
\hline PARAMETERS & $\mathbf{N}$ & $\begin{array}{l}\text { MPP1 } \\
\text { MEAN土SD }\end{array}$ & $\begin{array}{l}\text { ME } \\
\text { MEAN士SD }\end{array}$ & p-value* \\
\hline GLOMERULARDIAMETER( $\mu \mathrm{m})$ & 48 & $119,30 \pm 13,05$ & $123,26 \pm 14,19$ & \multirow[t]{5}{*}{$\mathrm{p}>0,05$} \\
\hline Control 1A (2h) & 12 & $115,31 \pm 10,41$ & $118,73 \pm 11,41$ & \\
\hline Control 1B (4h) & 12 & $115,31 \pm 11,41$ & $120,19 \pm 10,39$ & \\
\hline Group 2 (2h) & 12 & $125,12+9,18$ & $125,10 \pm 15,06$ & \\
\hline Group 3 (4h) & 12 & $121,46 \pm 18,11$ & $129,03 \pm 17,95$ & \\
\hline GLOMERULARAREA( $\mu \mathrm{m} 2)$ & 48 & $8954,5 \pm 1411,6$ & $9088,0 \pm 1414,8$ & \multirow[t]{5}{*}{$\mathrm{p}>0,05$} \\
\hline Control 1A (2h) & 12 & $8438,8 \pm 994,6$ & $8799,6 \pm 1407,9$ & \\
\hline Control 1B (4h) & 12 & $8511,0 \pm 1119,4$ & $8814,5 \pm 1086,3$ & \\
\hline Group 2 (2h) & 12 & $9591,2 \pm 1466,8$ & $9125,5 \pm 1502,3$ & \\
\hline Group 3 (4h) & 12 & $9276,8 \pm 1749,1$ & $9612,3 \pm 1630,8$ & \\
\hline MESANGIAL CELLS(n) & 48 & $21,1 \pm 2,8$ & $21,6 \pm 2,9$ & \multirow[t]{5}{*}{$\mathrm{p}>0,05$} \\
\hline Control 1A (2h) & 12 & $20,6 \pm 2,3$ & $20,4 \pm 2,1$ & \\
\hline Control 1B (4h) & 12 & $20,8 \pm 2,3$ & $21,9 \pm 2,4$ & \\
\hline Group 2 (2h) & 12 & $21,6 \pm 3,5$ & $22,8 \pm 3,0$ & \\
\hline Group 3 (4h) & 12 & $21,7 \pm 3,1$ & $21,4 \pm 3,9$ & \\
\hline
\end{tabular}

* t student test . MPP1 - Group $2>$ Control 1A (diameter and glomerular area) $\mathrm{p}<0,05$;

ME- Group $2>$ Control 1A (Mesangial cells) p=0,033.

\section{Discussion}

Laparoscopy with intraperitoneal gas insufflation and consequent increase of the abdominal pressure is associated to olyguria in humans and animals ${ }^{7}$. In healthy individuals with good renal function this condition is usually transient and leaves no sequelae. Considering the growing use of laparoscopy and the duration thereof, this subtle dysfunction may become clinically significant particularly when performed in patients with reduced renal reserve ${ }^{4}$.

A low urinary volume is still the most significant intraop effect, and it is pressure-dependant. In humans, performing a pneumoperitoneum at low pressure $(4 \mathrm{mmHg})$ does not lead to significant changes in the urinary output, plasmatic renal flow or glomerular filtration rate, unlike what has been seen with abdominal pressures higher than 12 mmHg ${ }^{9}$. Several mechanisms seem to be involved in such changes, including reduced cardiac output, compression of the renal vein, ureteric obstruction, compression of the renal parenchyma and systemic hormonal effects ${ }^{10}$. The duration of the ischemic effect resulting from the pneumoperitoneum in laparoscopy certainly has a direct effect on olyguria intensity and duration and histopatological damages that may involve the kidney. Transient dysfunction is observed at intra-abdominal pressures equal or higher than $10 \mathrm{mmHg}$ and/or exposure time to pneumoperitoneum above 60 minutes ${ }^{11}$. Pneumoperitoneum time used in this study was 2 and 4 hours under $15 \mathrm{mmHg}$ IAP, which corresponds to the mean values observed in different series involving laparoscopic nephrectomy in live donors ${ }^{6,12}$. Kirsch et al..$^{13}$ studying the effects o pneumoperitoneum on rat renal function used a 10 mmHg IAP during 2 and 4 hours and evidenced increased serum creatinine levels up to 2 hours after deflation, with a return to baseline values after that period ${ }^{13}$. In our study, serum creatinine levels did not significantly change in the rats submitted to a pneumoperitoneum for 2 and 4 hours, when they were assessed after 8 weeks and compared to the initial values in the intra-group analysis. Such results, therefore, confirm the transient nature of the renal dysfunction even in rats with a single kidney and after successive pneumoperitoneums. In control group $1 \mathrm{~B}$, however, when serum creatinine values at the beginning of the study (MPP1) were compared to values in the end of the study (ME), a statistically significant increase was observed $(0.34 \mathrm{mg} / \mathrm{dl} \times 0.40 \mathrm{mg} / \mathrm{dl}$; $\mathrm{p}=0.035)$, but had no clinical significance though, since those values are within the normal variation for rats. In several clinical and experimental studies, a strict correlation was seen between the increased volume and the degree of glomerular sclerosis that develops in several disease models or renal ablation ${ }^{14}$. Glomerular volume may be used as marker in high-risk patients or in those who have reduced renal mass, for function control on the long term ${ }^{15}$. Moreover, the glomerular change may be incremented through and additional factor resulting from the ischemia caused by high IAP during laparoscopy ${ }^{5}$. It is possible to make an accurate analysis of glomerular volume using different methods that, together, can determine the degree of glomerular involvement due to kidney damage. Among such methods we stress morphometric analysis for diameter and glomerular area quantification ${ }^{14}$. The analysis of data from this study on glomerular volume shows a significant difference only among animals in group 2 and control group $1 \mathrm{~A}$, at the beginning of the experiment, regarding glomerular area and diameter immediately after the first pneumoperitoneum (MPP1). This may have its origin in the glomerule sample collected for the morphometric study, since cortical glomerules are smaller in diameter than juxtamedullary glomerules ${ }^{16}$. When analyzing the glomerular hypertrophy degree by morphologic analysis performed after 8 weeks no significant difference was found among animals in groups 2 and 3 when compared to the control groups or even with the intra-group longitudinal study. The increased number of mesangial cells and/or cellularity seen in remnant kidneys has been interpreted as early morphological signs 
of glomerular damage. Mesangial hypercellularity may be considered as a risk factor for the development of renal lesions when the number of functional nephrons is reduced $^{14}$. This study's histological findings on the number of mesangial cells showed only a discreet increase (12\%) in animals of group 2 when compared to control group $1 \mathrm{~A}$ $(\mathrm{p}=0.033)$. This, however, was not seen in the group exposed to the pneumoperitoneum for a longer period (Group 3), which could more likely induce cell proliferation due to the greater ischemic effect. Possibly, the statistical significance found is related to the glomerule sample analyzed in this group, since the glomerular area and diameter variables were also higher in those animals. In this series, no evidence of focal or segmental glomerular sclerosis was found in the kidneys examined, regardless of the duration of the pneumoperitoneum to which the animals were exposed. The histomorphological analysis of the remnant kidneys has proved that prolonged and successive pneumoperitoneums are not directly related to glomerular damage in singlekidney rats. Such findings comply with reports in literature about the effects of pneumoperitoneum on the renal morphology of rats, that no harmful effects of increased IAP on the remnant kidney resulting from abdominal gas insufflation have been found ${ }^{4,5,13}$.

\section{Conclusion}

Renal function and morphology in rats submitted to unilateral nephrectomy are not significantly affected by prolonged and successive pneumoperitoneum when compared to animals whose IAP was not increased. Biochemical findings were histologically supported in this analysis.

\section{References}

1. Carry, P.Y.; Banssilon, V. Intra-abdominal pressure. Ann Fr Anesthesiol Reanim. 1994;13(3):381-99.

2. Bradley, S.E.; Bradley, G.P. The effect of increased intraabdominal pressures on renal function in man. J Clin Invest. 1947; 26(5):1010-22.

3. Ben-David, B.; Croitoru, M.; Gaitini, L. Acute renal failure following laparoscopic cholecystectomy: a case report. J Clin Anesth. 1999; 11(6):486-9.

4. Cisek, L.J.; Gobet, R.M.; Peters, C.A. Pneumoperitoneum produces reversible renal dysfunction in animals with normal and chronically reduced renal function. J Endourol. 1998; 12(2): 95-100.

5. Hazebroek, E.J.; de Bruin, R.W.F.; Bouvi, N.D.; Marquet,
R.L.; Bonthuis, F. Long-term impact of pneumoperitoneum used for laparoscopic donor nephrectomy on renal function and histomorphology in donor and recipients rats. Ann Surg. 2003; 237(3): 351-7.

6. Ruiz-Deya, G.; Cheng, S.; Palmer, E.; Thomas, R.; Slakey, D. Open donor, laparoscopic donor and hand assisted laparoscopic donor nephrectomy: a comparison of outcomes. J Urol. 2001;166(10): 1270-4.

7. Hazebroek, E.J.; Gommers, D.; Schreve, M.A.; Van Gelder, T.; Roodnat, J.I.; Weimar, W.; Bonjer, H.J.; Ijzermans, J.N.M. Impact of intraoperative donor management on short-term renal function after laparoscopic donor nephrectomy. Ann Surg. 2002; 236(1):127-32.

8. Lafferty, H.M.; Brenner, B.M. Are glomerular hypertension and hypertrophy independent risk factors for progression of renal disease? Semin Nephrol. 1990; 10(3):294-304.

9. Lindberg, F.; Bergqvist, D.; Björck, M.; Rasmussen, I. Renal hemodynamics during carbon dioxide penumoperitoneum: an experimental study in pigs. Surg Endosc. 2003; 17(3):480-4.

10. McDougall, E.M.; Monk, T.G.; Wolf JR, J.S.; Hicks, M.; Clayman, R.V.; Gardner, S.; Humphrey, P.A.; Sharp, T.; Martin, K. The effect of prolonged pneumoperitoneum on renal function in an animal model. J Am Coll Surg. 1996; 182(4):317-28.

11. Dunn, M.D.; McDougall, E.M. Renal physiology: laparoscopic considerations. Urol Clin North Am. 2000;27(4):609-14.

12. Jacobs, S.C.; Cho, E.; Foster, C.; Liao, P.; Bartleett, S.T. Laparoscopic donor nephrectomy: the University of Maryland 6-year experience. J Urol. 2004; 171(1):47-51.

13. Kirsch, A.J.; Hensle, T.W.; Chang, D.T.; Kayton, M.L.; Olsson, C.A.; Sawczuk, I.S. Renal effects of $\mathrm{CO}_{2}$ insuflattion: oliguria and acute renal dysfunction in a rat pneumoperitoneum model. Urology. 1994;43(4):453-9.

14. Fogo, A.; Hawkins, E.P.; Berry, P.L.; Glick, A.D.; Chiang, M.L.; MacDonell, R.C.; Ichikawa, I. Glomerular hypertrophy in minimal change disease predicts subsequent progression to focal glomerular sclerosis. Kidney Int. 1990;38(1):115-23.

15. Zeier, M.; Schönherr, R.; Amann, K.; Ritz, E. Effects of testosterone on glomerular growth after uninephrectomy. Nephrol Dial Transplant. 1998; 13:2234-40.

16. Hackbarth, H.; Büttner, D.; Jarck, D.; Pohmann, M.; Messow, C.; Gärtner, K. Distribution of glomeruli in the renal cortex of Munich Wistar Fromter rats. Ren Physiol. 1983;6(2):63-71.

\section{Correspondence: \\ Luiz Sergio Santos \\ Rua Visconde de Nácar, 865/cj 507 \\ 80410-201 Curitiba-PR Brazil \\ luizsergio@mps.com.br}

Conflict of interest: none

Financial source: none

Received: December 15,2004

Review: January 21, 2005

Accepted: February 18, 2005

\section{How to cite this article:}

Santos LS, Tambara Filho R, Figueiredo TMS, Cravo G. Effects of the pneumoperitoneum in rats submitted to a unilateral nephrectomy: morphologic and functional study on the remnant kidney. Acta Cir Bras [serial online] 2005 May-June;20(3). Available from URL: http://www.scielo.br/acb. 